\title{
Nest distribution and nesting habits of Xylocopa ordinaria Smith (Hymenoptera, Apidae) in a restinga area in the northern Rio de Janeiro State, Brazil
}

\author{
André Sarlo Bernardino $^{1} \&$ Maria Cristina Gaglianone ${ }^{1}$
}

${ }^{1}$ Laboratório de Ciências Ambientais, Universidade Estadual do Norte Fluminense Darcy Ribeiro - Av. Alberto Lamego, 2000 - Parque Califórnia, Campos dos Goytacazes-RJ, 28.013.602 bernardinoas@pop.com.br; mcrisgag@uenf.br

\begin{abstract}
Nest distribution and nesting habits of Xylocopa ordinaria Smith (Hymenoptera, Apidae) in the northern Rio de Janeiro State, Brazil. This paper aims to study the distribution of natural nests of Xylocopa ordinaria and characterize its nesting habits in the restinga of Grussai/Iquipari (RJ), supporting future studies on the pollinators management in the northern Rio de Janeiro state. The data obtained from Aug/2003 to Dec/2004, in an area of 11.6ha, were related to the nest distribution, substrate identification and dimensions, emergence, sex ratio, nest structure $(\mathrm{n}=23$ nests) and pollen content analysis of provisioning masses and feces. X. ordinaria nests were abundant and presented a clustered distribution. These bees do not present taxonomical affinity for nesting substrates, but preferences for wood availability and characteristics, being Pera glabrata the main substrate. $X$. ordinaria is a multivoltine species that tolerates co-specifics in their nests. These bees were generalist on their nectar and pollen consumption, but presented floral constancy while provisioning brood cells. These behaviors, activity along the year, flights throughout the day, and legitimate visits to flowers indicate the importance of $X$. ordinaria on the pollination of plants in the restinga.
\end{abstract}

KEYWORDS. Behavior; foraging; native bees; spatial distribution; Xylocopini.

RESUMO. Distribuição de ninhos e hábitos de nidificação de Xylocopa ordinaria Smith (Hymenoptera, Apidae) em área de restinga no norte do Estado do Rio de Janeiro, Brasil. Este artigo objetiva estudar a distribuição de ninhos naturais de Xylocopa ordinaria e caracterizar seus hábitos de nidificação na restinga de Grussai/Iquipari, fornecendo bases para estudos de manejo de polinizadores no Rio de Janeiro. Os dados foram obtidos entre Ago/2003 e Dez/2004, em uma área de 11,6ha, e correlacionados à distribuição dos ninhos, ao tipo de substrato e suas dimensões, à emergência, razão sexual, arquitetura do ninho $(\mathrm{n}=23)$ e ao conteúdo polínico presente em massas de aprovisionamento e fezes. Os ninhos de $X$. ordinaria foram abundantes e apresentaram distribuição agregada. Não foi verificada afinidade taxonômica por substratos de nidificação, mas quanto à disponibilidade e características da madeira, sendo Pera glabrata o substrato mais utilizado. $X$. ordinaria é uma espécie multivoltina que tolera a presença de co-específicos no ninho. Essas abelhas foram generalistas quanto às fontes de néctar e pólen, mas apresentaram constância floral no aprovisionamento de células de cria. Esses comportamentos, a atividade ao longo do ano, vôos ao longo do dia e visitas legítimas às flores indicam a importância de $X$. ordinaria na polinização de plantas da restinga.

PALAVRAS-CHAVE. Abelhas nativas; comportamento; distribuição espacial; forrageio; Xylocopini.

The restinga environment is geologically recent (Suguio et al. 1982), and is characterized as a group of ecosystems directly influenced by the ocean, presenting distinct plant community structures (Araújo \& Henriques 1984). Studies on the bee fauna in restinga ecosystems have shown great abundance of Xylocopa Latreille, 1802 (Apidae, Xylocopini) (Gottsberger et al. 1988, Viana \& Alves-dos-Santos 2002, Viana et al. 2002). These bees have been demonstrated as important pollinators of native plants because of their specialized behaviors on flowers and floral constancy (Buchmann 1983, Alves-dos-Santos 1999, Da Silva \& Viana 2002).

The genus Xylocopa presents more than 700 species, with 50 species in Brazil (Silveira et al. 2002). Xylocopa comprises some of the largest bees (Gerling et al. 1989), which excavate their nests in wood and present solitary habits, except for some species that tolerate co-specifics in their nests (Camilo \& Garófalo 1982, Camillo et al. 1986, Hogendoorn \& Velthuis 1993). Hurd (1958) suggested that nesting substrates are chosen through their wood characteristics, but not botanical affinity, and the distribution of nesting substrates has been pointed out as the most important factor on the distribution and occurrence of Xylocopa.

Gerling et al. (1989) highlighted the necessity of detailed studies on the nesting habits and characteristics of nesting substrates of most Xylocopa. In Brazil, the nesting biology was studied for $X$. (Neoxylocopa) frontalis (Olivier, 1789) and X. (N.) grisescens Lepeletier, 1841 (Camillo \& Garófalo 1982, Pereira 2002), for $X$. (N.) suspecta Moure \& Camargo, 1988, in trap-nests (Camillo et al. 1986), and for X. (Monoxylocopa) abbreviata Hurd \& Moure, 1963 (Ramalho et al. 2004). Studies on the ecology and nesting habits of $X$. cearensis Ducke, 1910 (Viana et al. 2002) and on the distribution of Xylocopa nests (Da Silva \& Viana 2002) were performed in a sand dunes area in Salvador, Bahia state.

Xylocopa (Neoxylocopa) ordinaria Smith, 1874 occurs in Brazil in the states of Bahia, Espírito Santo, Rio de Janeiro, 
Mato Grosso do Sul, São Paulo, and Rio Grande do Sul (Silveira et al. 2002). These bees were indicated as effective pollinators of Passiflora alata Curtis, 1788 (Varassin \& Silva 1999), and of yellow passion fruit, Passiflora edulis f. flavicarpa Deg, 1932 (Hoffmann et al. 2000). Data on biology and nesting habits of $X$. ordinaria are not available in the literature (Schlindwein $e t$ al. 2003).

In the restinga of Grussai/Iquipari Lagunar Complex, São João da Barra - Rio de Janeiro state, X. ordinaria is very abundant, and represented $98 \%$ of the carpenter bees, and $21 \%$ of all collected bees in a one-year flower-visiting bee survey performed. Observations of $X$. ordinaria on flowers suggest its importance as pollinator of many plant species in this area.

The objectives of this paper are to study the distribution of natural nests of $X$. ordinaria and to characterize its nesting habits in the restinga of Grussai/Iquipari Lagunar Complex, São João da Barra - Rio de Janeiro state, in order to obtain a better comprehension about its interactions with the environment, offering support for future studies on the pollinators management in the northern Rio de Janeiro state.

\section{MATERIAL \& METHODS}

The study was carried out in the restinga of Grussai/ Iquipari Lagunar Complex, located in São João da Barra, northern Rio de Janeiro state, Brazil $\left(21^{\circ} 44^{\prime} \mathrm{S}\right.$; $\left.41^{\circ} 02^{\prime} \mathrm{W}\right)$. RadamBrasil (1983) defines the climate of this region as tropical sub-humid to semi-arid, with mean annual precipitation ranging from 800 to $1200 \mathrm{~mm}$, and the highest precipitation rates on summer (October - March) and the lowest on winter (April September).

Assumpção \& Nascimento (2000) studying the vegetation communities in this restinga, draw attention to its unique characteristics and pointed out this ecosystem as a new element in the vegetation mosaic along the Brazilian coastal areas. After that, they proposed the distinction of four phytophysiognomies of the vegetation of the restinga of Grussai/Iquipari Lagunar Complex: Beach Grass formation, Beach Grass and Shrub formation, Clusia formation and Restinga Forest formation.

The nests of $X$. ordinaria were searched out by two observers between 09:00a.m. and 04:00p.m., from Aug/2003 to Dec/2004, in a line of $5,800 \mathrm{~m}$ length perpendicular to the tidal line, passing through the four phytophysiognomies defined by Assumpção \& Nascimento (2000). The nests were sought in a $10 \mathrm{~m}$ buffer along the transect, summing up to an area of 11.6ha. Nests were marked with numbered targets and the measurements of the entrance height above ground, entrance diameter and substrate circumference were taken. The host plant material was collected for identification and deposited in the Herbarium of the "Centro de Biociências e Biotecnologia" of the "Universidade Estadual do Norte Fluminense (UENF)". With a GPS device the nested places were marked in order to perform the nest distribution analysis and correlation with the phytophysiognomies.
The nesting activity was investigated through a survey of bees on flowers from Jan/2003 to Dec/2003 and from observations of occupied and unoccupied nests between Aug/ 2003 and Dec/2004. In that survey, the bees were captured on flowers, monthly, by three collectors from 08:00a.m. to 04:00p.m., using entomological nets. The wing wear of $X$. ordinaria specimens captured in that survey were evaluated following Camillo \& Garófalo (1989).

Observations of nesting activity throughout the day were carried out in September $20^{\text {th }}, 21^{\text {st }}$ and $23^{\text {rd }}$ of 2004 for one nest, using a digital video camera to record the construction and provisioning behaviors, as well as the activities performed by the female.

From the marked nests, $30 \%$ were randomly collected and taken to the laboratory at the end of the observations to register the emergence and to identify the sexual ratio of this population. After the emergences, the internal measurements of the nests were taken as follows: tunnel length, cell length, cell diameter and operculum width.

The difference between dry and wet weight of two provisioning masses was analyzed before and after drying in air circulation stoven at $40^{\circ} \mathrm{C}$ per 120 hours. The analysis of pollen morphotypes used by $X$. ordinaria was made from provisioning masses and feces taken from 17 provisioning cells of 13 nests collected in Sept-Oct/2004. The pollen material was prepared in slides with gelatine-fuchsin (Dafni, 1992). The different pollen morphotypes presented in each studied cell were identified through analysis of two pollen slides, prepared from each homogenized provisioning mass sample. In each slide 200 pollen grains were randomly counted and calculated the proportion of each pollen morphotype.

The nest distribution analysis followed the fit to the Poisson Distribution, through the analysis of the variance/ mean index (Valdermeer \& Goldberg 2003). For this analysis, the sampled area of 11.6ha was divided into 58 quadrats of $100 \times 20 \mathrm{~m}(0.2 \mathrm{ha})$, and the nests presented in each quadrat were plotted as frequency of occurrence/quadrat.

Data on height above ground and circumference of nested substrates in the different phytophysiognomies were compared with the non-parametric test of Mann-Whitney (CallegariJacques 2004). In these analyses, Shrub formation and Clusia formation were considered together into one variable and Restinga Forest formation into another, since the data collected for the Shrub formation occurred in a transitional area Shrub/ Clusia.

\section{RESULTS}

Between Aug/2003 and Dec/2004, 75 nests of X. ordinaria were found, from which $44 \%$ were habited by adults and the other $56 \%$ were marked (without activity or abandoned) due to entrance characteristics, such as: diameter, presence of fragments of wood (sawdust) at the entrance of the nest or nearby it. Although there are other two Xylocopa species in the area $(X .(N$.$) frontalis and X$. (Schonnherria) macrops Lepeletier, 1841), the nests identification by indirect 
characteristics was possible because of the relative abundance of X. ordinaria (98\%) compared to the other two Xylocopa species and due to the great difference among their body sizes.

The density of nests in the study area was 6.5 nests/ha. When the phytophysiognomies were considered separately, the Shrub/Clusia area presented a nest density of 4.5 nests/ ha and the Restinga Forest presented 7.6 nests/ha. The nests occurred in the Restinga Forest formation (72\%), Clusia formation (24\%) and Shrub/Clusia formation (4\%), while no nests were found at the Beach Grass formation, where trees and shrubs are absent.

It was easier to find $X$. ordinaria nests after had found a first one on the same tree or on nearby trees, which suggested a clustered distribution. The variance/mean index analysis returned a value of 1.32 for the entire sampled area; but when the areas were analyzed separately, it returned values of 1.56 and 1.18 for the Shrub/Clusia area and Restinga Forest formation, respectively. Therefore, although the distribution may be considered clustered, the clustering level in the Restinga Forest is lower than in the Shrub/Clusia when the areas were considered separately.

All observed nests were excavated in dry rotten branches that presented no cracks or fissures, and could be found in live plants or broken branches upon the vegetation. The nests were dug in dry branches of Pera glabrata (Schott) Poepp. ex Baill, Euphorbiaceae (76\%), dead branches of Sideroxylon obtusifolium (Humb. ex Roem. \& Schult.) T.D. Penn., Sapotaceae (6\%), branches of Eugenia ovalifolia Cambess. Myrtaceae (1\%) and non-identified dry branches (17\%).

The circumference of the substrates used by these bees ranged from 7 to $25.5 \mathrm{~cm}$ (mean $=12.38 \pm 4.14, \mathrm{n}=62$; Table $\mathrm{I})$, and most of them $(75.8 \%)$ presented less than $15 \mathrm{~cm}$. The entrance height above ground ranged from 30 to $400 \mathrm{~cm}$ (mean= $162.89 \pm 76.59, \mathrm{n}=75$; Table I), with $74.7 \%$ of the nests between 80 and $240 \mathrm{~cm}$.

The circumference of substrates used in the Shrub/Clusia area and Restinga Forest formation did not show statistical difference (Mann-Withney, Z $=0.46, p>0.05$; Table I), while the entrance height above ground was significantly higher in the Restinga Forest formation (Mann-Withney, $\mathrm{Z}=2.21, p<0.05$; Table I).

The nests of $X$. ordinaria had elliptical entrance, with the greater diameter ranging from 1.2 to $1.8 \mathrm{~cm}$ and with $90.2 \%$ of nests presenting entrance diameters between 1.3 and $1.5 \mathrm{~cm}$. The nests consisted of one to four tunnels, which have a vestibule and smooth walls. From the total sampled nests, $72.7 \%$ consisted of only one tunnel. The nests could have one to nine cells, which were barrel shaped and closed with an operculum made of wood dust (Table II). The operculum had two distinct surfaces: a rough and concave inner side and a smooth outer side.

From the 30 cells kept in the laboratory, 26 bees ( 11 males and 15 females) emerged, resulting in a sex ratio of 0.73 males/ females. Two cells were infected by fungus and one cell was found without provisioning mass or immature. One adult of the cleptoparasite Cissites maculata Swederus, 1787

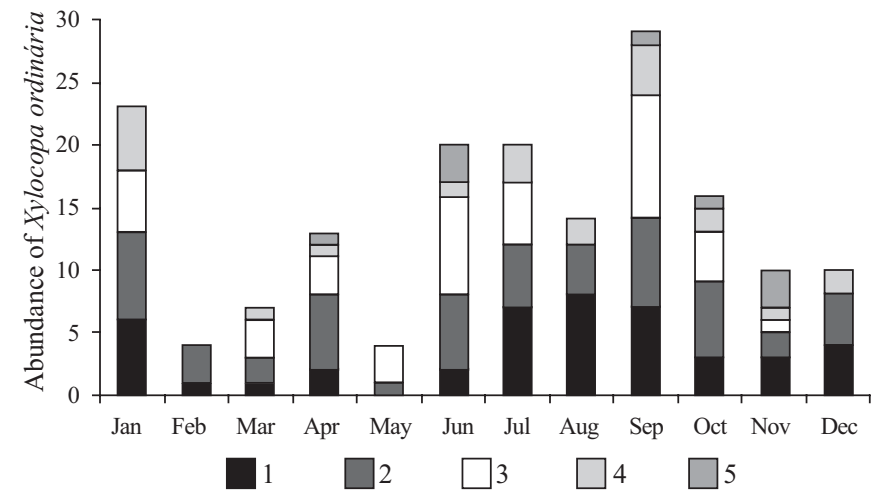

Fig. 1. Abundance of females of Xylocopa ordinaria collected on flowers through out the year 2003 and number of females with different wing wear per month $(1=$ young female to $5=$ old female - as described by Camillo \& Garófalo 1989).

(Coleoptera, Meloidae) emerged from a X. ordinaria cell in Sep/2004.

Data of flower visiting bees showed active females along the whole year. Young females of X. ordinaria $\left(1^{\text {st }}\right.$ stage of wing wear after Camillo \& Garófalo 1989) were found on flowers on almost every month (except on May), with higher frequency between July and September (Fig. 1). Occupied nests were registered along the whole observation period, with higher relative abundance between July and December (Fig. 2). From the 33 nests observed with adults (44\%), 14 had more than one female in their interior.

Table III indicates the plant species used by $X$. ordinaria in the restinga of Grussai/Iquipari Lagunar Complex for pollen and nectar collection. X. ordinaria was observed collecting pollen of Solanum curvispinum Dun., Clusia hilariana Schletch, Allagoptera arenaria (Gomes) Kuntze, and Byrsonima sericea DC. On poricidal flowers of S. curvispitum, $X$. ordinaria performed the vibration behavior (buzz pollination) to collect pollen. On the other flowers the foraging behavior was unspecialized. On their nectar foraging flights, $X$. ordinaria visited Arrabidaea conjugata (Vell.) Mart., Mandevilla funiformis (Vell.) K. Scum, Manilkara subsericea

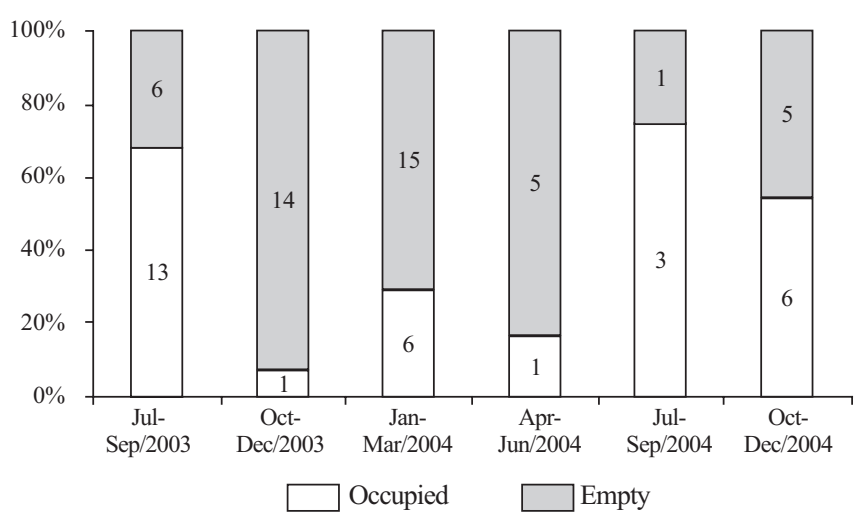

Fig. 2. Percentage of occupied and empty nests of Xylocopa ordinaria in the restinga of Grussai/Iquipari Lagunar Complex (numbers inside the bars correspond to the absolute number of nests). 
Table I. Characterization of nesting substrates of Xylocopa ordinaria on two phytophysiognomies of the restinga of Grussai/Iquipari Lagunar Complex, São João da Barra, RJ.

\begin{tabular}{|c|c|c|c|}
\hline Area & Entrance height above ground & Circumference of nested substrates & Nested host plant species \\
\hline $\begin{array}{l}\text { Shrub + Clusia } \\
\text { formations }\end{array}$ & $\begin{array}{c}35-250 \mathrm{~cm} \\
(\text { mean }=134.9 \pm 62.4, \mathrm{n}=21)^{*}\end{array}$ & $\begin{array}{c}7-23 \mathrm{~cm} \\
(\text { mean }=12.4 \pm 4.8, n=18)\end{array}$ & $\begin{array}{l}\text { Pera glabrata and dry branches of } \\
\text { unidentified species }\end{array}$ \\
\hline $\begin{array}{l}\text { Restinga Forest } \\
\text { formation }\end{array}$ & $\begin{array}{c}30-400 \mathrm{~cm} \\
(m e a n=175.5 \pm 74.7, \mathrm{n}=53)^{*}\end{array}$ & $\begin{array}{c}7-25.5 \mathrm{~cm} \\
(\text { mean }=12.3 \pm 3.8, \mathrm{n}=46)\end{array}$ & $\begin{array}{c}\text { Pera glabrata, Sideroxylon obtusifolium, } \\
\text { Eugenia ovalifolia and dry branches of } \\
\text { unidentified species }\end{array}$ \\
\hline
\end{tabular}

* significant differences (Mann-Withney, $\mathrm{Z}=2.21, \mathrm{p}<0.05)$.

(Mart.) Dubard., Passiflora alliacea Barb. Rodr., and Centrosema brasilianum (L.) Benth. as its main nectar sources. The first two plant species have long tubular corollas that demands long proboscis for legitimate nectar collection. On M. funiformis flowers, females of $X$. ordinaria were robbers, as they pierced the base of the corolla with their galls and did not contact the reproductive organs of the flowers. This thief behavior was also observed in some flowers of $C$. brasilianum, which the specialized morphology requires large bees for pollination, preventing the access to nectar from small bees. $X$. ordinaria also visited P. alliacea as a nectar source, and its body size and behavior on flowers are adequate for pollination.

One observation of dehydration behavior was made, when a female of $X$. ordinaria was underneath a leaf exposed to the sun. For $14 \mathrm{~min}$ and $30 \mathrm{sec}$, the female opened and closed its galls several times, and a drop of nectar flowed to the top of the tongue being ingested again.

The analysis of the provisioning mass from two cells of the same nest showed that $23 \%$ and $20 \%$ of their weight was liquid. The analysis of provisioning masses or feces from 17 cells demonstrated the use of 16 pollen morphotypes, where two to five pollen morphotypes could be found in a single cell. The provisioning mass is homogeneous and has a predominant pollen type (mean $=76.3 \% \pm 17.7 \%, \mathrm{n}=17)$, but other pollen morphotypes could be found.

The time spent on the provisioning activity was very variable, as a consequence of the time spent on the search for floral resources and availability of pollen. The nectar flights could occur while collecting pollen or after provisioning the cell with pollen. The flights for pollen collection lasted from three to eight minutes (mean=5.01 $\pm 1.64, \mathrm{n}=9$ ) and the flights for nectar collection or feeding lasted from 1 to 65 minutes (mean=11.49 $\pm 16.34, \mathrm{n}=29$ ).

\section{DISCUSSION}

The nests of $X$. ordinaria in the restinga of Grussai/ Iquipari Lagunar Complex presented a higher density (6.5nests/he) when compared to the study performed by Da Silva \& Viana (2002) for nests of X. cearensis (4.4nests/he), but similar to this species, the nests of $X$. ordinaria presented a clustered distribution. This distribution pattern may be related to the philopatry behavior presented by some Xylocopa species (Camillo \& Garófalo 1989) or to restrictions imposed by nesting substrates distribution (Camillo \& Garófalo 1989, Gerling et al. 1989, Hogendoorn \& Velthuis 1993, Da Silva \& Viana 2002). The last hypothesis is reinforced by the greater values of the variance/mean index for the Shrub/Clusia area compared to the Restinga Forest formation. The substrates at the first area are distributed in patches as a consequence of this plant community structure (Assumpção \& Nascimento 2000, Esteves \& Lacerda 2000), where the bushes environment facilitates the germination and growing of other plant species, such as the host plants of nests, and could directly influence the nests distribution.

The hypothesis of environmental restriction on the nest distribution is also corroborated when considering the study on the plant community structure of the restinga of Grussai/ Iquipari Lagunar Complex (Assumpção \& Nascimento 2000): 1. the absence of nests at the Beach Grass formation was expected, because shrubs or trees that would host nests are absent (Assumpção \& Nascimento 2000); 2. at the Shrub/ Clusia area the lower density of nests, compared to the Restinga Forest formation, may be correlated with the rare occurrence of potential nesting substrates. As indicated by Assumpção \& Nascimento (2000), the main shrub species in this area are Schinus terebinthifolia Raddi, Anacardiaceae and Eugenia sulcata Spring ex Martius, Myrtaceae, pointed out by Lorenzi $(2002$ a,b) as hard and resistant to decomposition. These characteristics are unfavorable to excavation by Xylocopa species, which in general use soft substrates or substrates at the beginning of the decomposition process (Hurd 1958, Gerling et al. 1989). Besides that, the circumferences of the branches at the Beach Grass and Shrub formation are very small and probably inadequate to $X$. ordinaria; 3 . the higher density of $X$. ordinaria nests at the Restinga Forest formation is associated with the distribution

Table II. Internal measurements of Xylocopa ordinaria nests collected from different substrates of the restinga of Grussai/Iquipari Lagunar Complex (measurements in $\mathrm{cm}$ ).

\begin{tabular}{lc}
\hline Nest Characteristics & Range $($ mean $\pm \mathrm{SD}, \mathrm{n})$ \\
\hline Number of brood cells & $1-9(4.63 \pm 2.14,19)$ \\
Tunnel length & $7.1-38.0(15.67 \pm 7.21,25)$ \\
Cell Length & $1.50-2.64(2.05 \pm 0.27,81)$ \\
Cell width & $1.36-1.84(1.56 \pm 0.11,83)$ \\
Operculum width & $0.14-0.65(0.36 \pm 0.13,51)$ \\
\hline
\end{tabular}

$\mathrm{SD}=$ Standard Deviation and $\mathrm{n}=$ number of observations. 
Table III. Plant species used as nectar and pollen resources by Xylocopa ordinaria in the restinga of Grussai/Iquipari Lagunar Complex, São João da Barra, RJ.

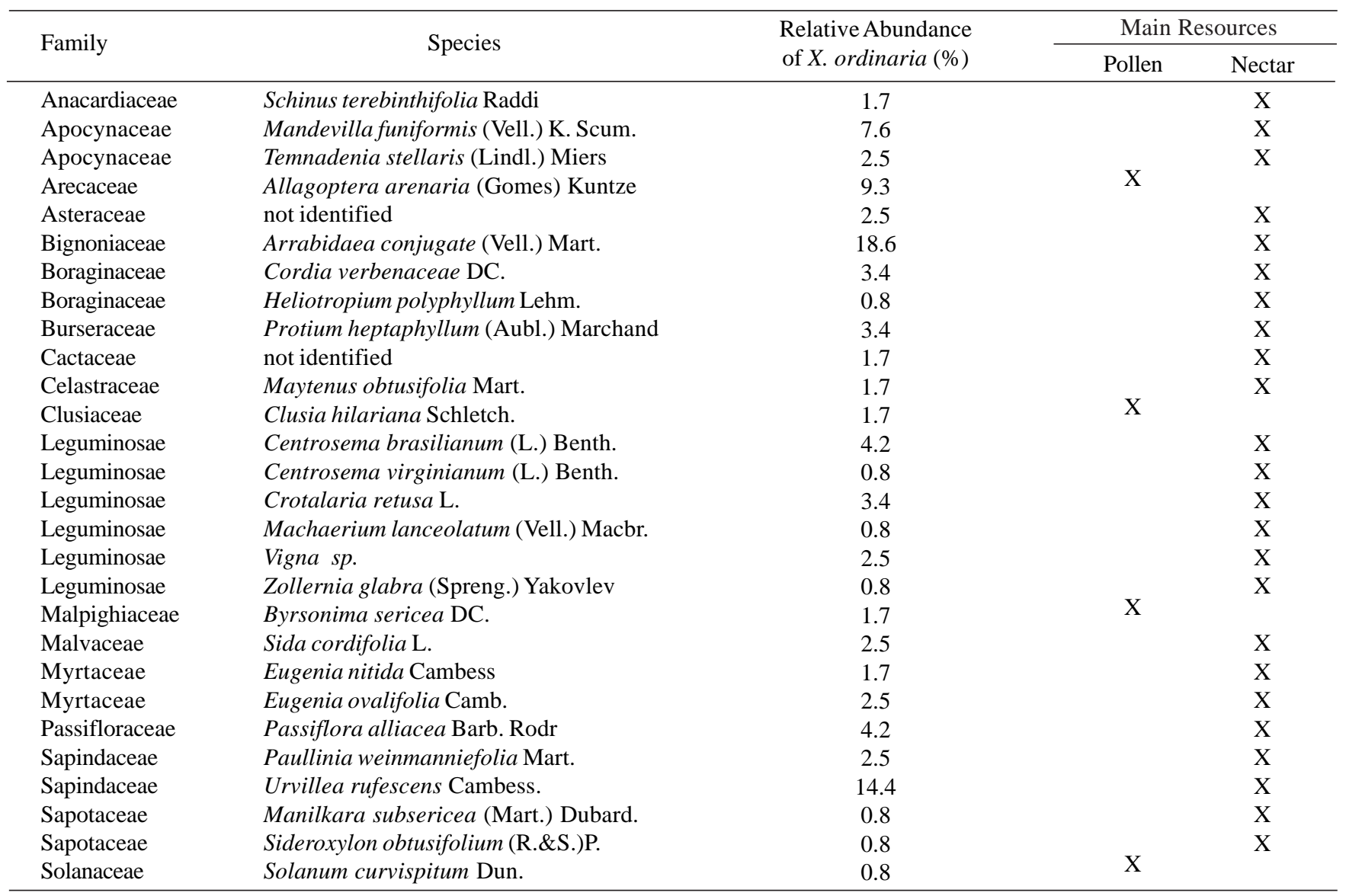

and occurrence of its main nesting substrates (P. glabrata and S. obtusifolium) at the study area (Assumpção \& Nascimento 2000).

Assumpção \& Nascimento (2000) considered P. glabrata as the most representative plant species of the Restinga Forest and Clusia formations, as a consequence of its high coverage index (relative frequency $\mathrm{X}$ relative coverage). Other factors that could contribute for the high frequency of nests in $P$. glabrata are the great number of branched plants at these areas (Assumpção \& Nascimento 2000) and the characteristics of soft wood (Lorenzi 2002a). The higher frequency of nests in S. obtusifolium occurs at the most inner region of the Restinga Forest formation, which coincides with its area of greater relative frequency (Assumpção \& Nascimento 2000).

The analysis of the nesting substrates used by $X$. ordinaria suggests that there are preferences for certain characteristics and abundance of substrates, independent of botanical affinity, as described for $X$. frontalis and X. grisescens (Camilo \& Garófalo 1982, Pereira 2002), X. suspecta (Camillo et al. 1986), X. pubescens (Spinola) (Hogendoorn \& Velthuis 1993, 1995 ), and $X$. cearensis (Da Silva \& Viana 2002, Viana et al. 2002). Specificity to host plant species was observed for $X$. virginica (Linn.), X. ciliate Burmeister, 1876, and $X$. artifex Smith, 1874 (Gerling et al. 1989), and a strict association between $X$. abbreviata and Echolirium espectabile (Bromeliaceae) was described by Ramalho et al. (2004).

The substrate's circumference and the nest entrance height above ground were similar to that described for other Xylocopa species studied by Da Silva \& Viana (2002). The frequency of nests at circumference intervals did not show significant difference between the two areas, therefore it is not possible to evaluate if there are preferences for these substrate's circumferences or if it is an ecological restriction imposed by the phenotypic characteristics of the host plant species in the restinga of Grussai/Iquipari Lagunar Complex. Studies on this preference should be performed in areas that present distinct plant structure characteristics. On the other hand, the analysis considering the variation of nest entrance height above ground revealed that it is higher at the Restinga Forest formation, area that presents taller plants (Assumpção \& Nascimento 2000), suggesting that it is directly influenced by the vegetation characteristics.

The nests of $X$. ordinaria presented characteristics very similar to the nests of other Xylocopa species, such as number and shape of cells, number and length of tunnels and shape of the entrance (Camilo et al. 1982, Fernández \& Parra 1985, Camilo et al. 1986, Gerling et al. 1989). However variations between cells of males and females are common (Steen \& Schwars 2000, 
Pereira 2002, Ramalho et al. 2004) they were not considered in the present analysis.

Most nests of $X$. ordinaria presented a single tunnel, which could be determined by characteristics of the host plant species or by the circumference of the host substrate, as observed by Steen \& Schwars (2000) for X. bombylans Smith nesting in plants of the genus Banksia, and by Ramalho et al. (2004) for $X$. abbreviata nesting in stems of E. espectabile. However, nests with more than one tunnel and more than one female were also observed. These are important factors for studies on intra-specific interactions inside the nest, determination of foraging and reproduction strategies, as well as distribution of tasks inside the nest (Hogendoorn \& Velthuis 1993, 1995, 1999; Hogendoorn 1996), indicating $X$. ordinaria as a new potential species for studies concerning the evolution of social behavior among the carpenter bees (Michener 1974).

The causes of death of immatures of $X$. ordinaria were infestation of brood cells by fungus and cleptoparasitism by Coleoptera of the genus Cissites. The infestation by fungus has been described as one of the main causes of immature death (Gerling et al. 1989, Roubik 1989, Pereira 2002). On the other hand, the cleptoparasitism by species of Cissites, also reported by other authors (Hurd 1958, Gerling et al. 1989, Roubik 1989, Pereira 2002) was highlighted as a strict association of Cissites to Xylocopa species (Pinto \& Bologna 1999).

The data of bees on flowers and the occurrence of occupied nests along the whole year suggest that $X$. ordinaria is a multivoltine species, presenting more than two generations per year. Though multivoltine, $X$. ordinaria presented greater nesting activity between July and December, and it could be associated with greater offer of flower resources in the area. Watmough (1983), studying the mortality, sexual ratio and fecundity of natural populations of carpenter bees, demonstrated that multivoltine species produce less individuals per generation, but the sum of the total individuals produced along a period of time is higher than the number produced by univoltine species, being the voltinism determinant of reproduction strategy and parental care.

From the data of flower visiting bees, we could identify the generalist habit of $X$. ordinaria for nectar flowers. These bees visited flowers with different morphologies and from different botanical families, where it could present specialized and legitimate behaviors acting as an effective pollinator. But in some species, $X$. ordinaria behave as a robber by perforating the corolla to reach the nectar, hidden in the deeper part of the flower and did not act as pollinators. Similar observations were made for other Xylocopa species in different ecosystems (Gottsberger et al. 1988, Gerling et al. 1989, Pereira 2002, Viana et al. 2002).

The results from the pollen analyses indicate $X$. ordinaria as a polilectic species on the gathering of pollen, using more than 16 different pollen morphotypes at the same period of the year to feed their brood. The presence of a predominant pollen morphotype in each provisioning mass indicates the effectiveness of $X$. ordinaria as pollinator of plants in the restinga of Grussai/Iquipari Lagunar Complex, since many visits to flowers of the same plant species are necessary to provisioning each brood cell (Buchmann 1983, Buchmann \& Nabhan 1996).
Our observation of nectar dehydrating behavior was different from the ones made by Camillo \& Garófalo (1982, 1989), Camillo et al. (1986) and Pereira (2002). They observed females dehydrating nectar at the entrance of the nest and, right after this behavior, the nectar will be transferred to the provisioning mass. The behavior of dehydrating nectar while foraging was also observed for males of X. nigrocincta Smith, 1854 (Wittmann \& Scholz 1987). According to these authors, the dehydration increases the ratio energy/volume of nectar, which allows the males to persist more time on their mating territories. The nectar dehydration made by $X$. ordinaria females out of their nests might be related to the high energy demand associated to the time spent at foraging flights or to the deposition of this more concentrated nectar in the provisioning masses. The last hypothesis is corroborated by the small difference between wet and dry weight found for provisioning masses $(\sim 20 \%)$, indicating that only a small portion of provisioning masses is water.

Visits to flowers were observed all over the day, from early in the morning (05:00a.m.) through the end of the afternoon (06:00p.m.). This foraging flight behavior was also observed for other Xylocopa species, and Gerling et al. (1989) and Viana et al. (2002) highlighted that these bees can present floral constancy associated with the abundance of flower species on certain hours of the day. The time spent on foraging flights for pollen and nectar, as well as the time spent inside the nest, varied much, likely other Xylocopa species (Camillo \& Garófalo 1982, Camillo et al. 1986, Gerling et al. 1989, Pereira 2002). These behaviors could be related to the flight distance to flower resources, as well as the type of activity performed by the female (pollen or nectar collecting, deposition and manipulation of food inside the brood cells, excavation activities). In order to better understand the nest construction and provisioning strategies, more detailed studies should be made concerning time spent in each activity and sequence of activities performed by females.

The present study demonstrated the great abundance and the clustered distribution pattern of $X$. ordinaria nests at the restinga of Grussai/Iquipari Lagunar Complex, and has suggested that these bees do not present botanical affinity for nesting substrates, but have preferences for wood availability and characteristics. $X$. ordinaria was characterized as a multivoltine species that tolerates co-specifics in their nests, indicating some level of sociality. These bees were generalist on their nectar and pollen consumption, but presented floral constancy while provisioning each brood cell with pollen. These behaviors summed to their activity along the year, flights through out the day, legitimate visits to flowers at period of greater blossoms indicate the importance of $X$. ordinaria on the pollination of plants in the restinga and suggest its utility for sustainable pollinator management programs of native and cultivated plants.

Acknowledgement. The authors are grateful to João Marcelo Alvarenga Braga (JBRJ) for the identification of the plant species, and to FAPERJ (E26/171.622/2002) and PROBIO-Polinizadores (011500/04) for the financial support. We are also thankful to PIBIC/UENF for the scientific initiation grant to the first author. This is a contribution of the Graduate Program of Ecology and Natural Resources / UENF. 


\section{REFERENCES}

Araújo, D. S. D \& R. P. B. Henriques. 1984. Análise florística das Restingas do Estado do Rio de Janeiro. P. 159-194. In: L. D. Lacerda et al (org.) Restingas: Origem, Estrutura e Processos. Niterói, CEUFF.

Assumpção, J. \& M. T. Nascimento. 2000. Estrutura e composição florística de quatro formações vegetais de restinga no complexo lagunar Grussaí/Iquipari, São João da Barra, RJ, Brasil. Acta Botânica Brasilica 14: $301-315$.

Alves-dos-Santos, I. 1999. Abelhas e plantas melíferas da mata atlântica, restinga e dunas do litoral norte do estado do Rio Grande do Sul, Brasil. Revista Brasileira de Entomologia 43: 191-223.

Buchmann, S. L. 1983. Buzz pollination in Angiosperms. p. 73-113. In: C. E. Jones \& R. J. Little (eds.) Handbook of experimental pollination biology. New York, Scientific and Academic Editions. $558 \mathrm{p}$.

Buchmann, S. L. \& G. P. Nabhan. 1996. The forgotten pollinators. Washington D. C, Island Press/Sheawater Books. 292 p.

Callegari-Jacques, S. M. 2004. Bioestatística: princípios e aplicações. Porto Alegre, Artmed Editora. 255 p.

Camillo, E. \& C. A. Garófalo. 1982. On the bionomics of Xylocopa frontalis (Oliver) and Xylocopa grisescens (Lepeletier) in southern Brazil. I. Nest construction and biological cycle. Revista Brasileira de Biologia 42: 571-582.

Camillo, E.; C. A. Garófalo \& G. Muccillo. 1986. On the bionomics of Xylocopa suspecta (Moure) in the southern Brazil: nest construction and biological cycle (Hymenoptera, Anthophoridae). Revista Brasileira de Biologia 46: 383-393.

Camillo, E. \& C. A. Garófalo. 1989. Social organization in reactivated nests of three species of Xylocopa (Hymenoptera, Anthophoridae) in southeastern Brazil. Insectes Sociaux 36: 92-105.

Da Silva, F. O. \& B. F. Viana. 2002. Distribuição de ninhos de abelhas Xylocopa (Hymenoptera: Apidae) em uma área de dunas litorâneas. Neotropical Entomology 3: 661-664.

Dafni, A. 1992. Pollination Ecology - A practical Approach. Oxford University Press. 250 pp.

Esteves, F. A. \& L. D. Lacerda. 2000. Ecologia de restingas e lagoas costeiras. Macaé, NUPEM/UFRJ. 446 p.

Fernández, F. \& G. N. Parra. 1985. Habitos de nidificacion en abejas carpinteras del genero Xylocopa (Hymenoptera: Anthophoridae). Revista Colombiana de Entomologia 11: 36-41.

Gottsberger, G.; J. M. F. Camargo \& I. S. Gottsberger. 1988. A beepollinated tropical community: the beach dune vegetation of Ilha de São Luiz, MA , Brazil. Botanische Jahrbuecher fuer Systematik Pflanzengeschichte und Pflanzengeographie 109: 469-500.

Gerling, D.; H. H. W. Velthuis \& A. Hefetz. 1989. Bionomics of the large carpenters bees of the genus Xylocopa. Annual Review of Entomology 34: 163-190.

Hoffmann, M.; T. N. S. Pereira; M. B. Mercadante \& A. R. Gomes. 2000. Polinização de Passiflora edulis f. flavicarpa (Passiflorales, Passifloraceae), por abelhas (Hymenoptera, Anthophoridae) em Campos dos Goytacazes, Rio de Janeiro. Iheringia 89: 149-152.

Hogendoorn, K. 1996. Socio-economics of brood destruction during supersedure in the carpenter bee Xylocopa pubescens. Journal of Evolutionary Biology 9: 931-352.

Hogendoorn, K. \& H. H. W. Velthuis. 1993. The sociality of Xylcopa pubescens: does a helper really help? Behavioral Ecology and Sociobiology 32: 247-257.

Hogendoorn, K. \& H. H. W. Velthuis. 1995. The role of young guards in Xylocopa pubescens. Insectes Sociaux 42: 427-448.

Hogendoorn, K. \& H. H. W. Velthuis. 1999. Task allocation and reproductive skew in social mass provisionaing carpenter bees in relation to age and size. Insectes Sociaux 46: 198-207.
Hurd, P. D. 1958. Observations on the nesting habits of some new world carpenter bees with remarks on their importance in the problem of species formation (Hymenoptera: Apoidea). Annals of the Entomological Society of America 51: 365-375.

Lorenzi, H. 2002a. Árvores brasileiras: manual de identificação e cultivo de plantas arbóreas do Brasil, Vol. 1, 4 ${ }^{\mathrm{a}}$ edição, Editora Nova Odessa, SP: Instituto Plantarum.

Lorenzi, H. 2002b. Árvores brasileiras: manual de identificação e cultivo de plantas arbóreas do Brasil, Vol. 2, 2a edição, Editora Nova Odessa, SP: Instituto Plantarum.

Michener, C. D. 1974. The social behavior of the bees. Cambridge, Harvard University Press. 404 p.

Pereira, M. 2002. Biologia de nidificação de Xylocopa frontalis e Xylocopa grisescens (Hymenoptera, Apidae, Xylocopini) em ninhos armadilha. Tese de doutoramento. Faculdade de Filosofia Ciências e Letras - USP- Ribeirão Preto.

Pinto, J. D. \& M. A. Bologna. 1999. The New World genera of Meloidae (Coleoptera): a key and synopsis. Journal of Natural History 33: $569-620$.

Radambrasil. 1983. Rio de Janeiro/Vitória; Geologia, Geomorfologia, Pedologia, Vegetação e Uso potencial da terra - SF. 23/24. Projeto RADAMBRASIL, Rio de Janeiro.

Ramalho, M.; M. A. Batista \& M. Silva. 2004. Xylocopa (Monoxylocopa) abbreviata Hurd \& Moure (Hymenoptera:Apidae) e Encholirium spectabile (Bromeliaceae): Uma Associação estreita no Semi-Árido do Brasil Tropical. Neotropical Entomology 33: 417-425.

Roubik, D. W. 1989. Ecology and natural history of the tropical bees. Cambridge University. 514 p.

Silveira, F. A.; G. A. R. Melo \& E. A. B. Almeida. 2002. Abelhas brasileiras: sistemática e identificação. Belo Horizonte, 253p.

Schlindwein, C.; B. Schlumpberger; D. Wittmann \& J. S. Moure. 2003. O gênero Xylocopa Latreille no Rio Grande do Sul, Brasil (Hymenoptera; Anthophoridae). Revista Brasileira de Entomologia 47: 107-118.

Steen, Z. \& M. P. Schwars. 2000. Nesting and life cycle of the Australian green carpenter bees Xylocopa (Lestis) aeratus Smith and Xylocopa (Lestis) bombylans (Fabricius) (Hymenoptera: Apidae: Xylocopinae). Australian Journal of Entomology 39: 291300 .

Suguio, K; L. Martin \& J. M. L. Dominguez. 1982. Evolução da planície costeira do rio Doce (ES) durante o Quaternário: Influência das flutuações do nível do mar. Atas do IV Simpósio do Quaternário no Brasil: 93-116.

Valdermeer, J. H. \& D. E. Goldberg. 2003. Population Ecology First Principles. Princeton. 260 p.

Varassin, I. G. \& A. G. Silva. 1999. A melitofilia em Passiflora alata Dryander (Passifloraceae), em vegetação de restinga. Rodriguesia 50: $5-17$.

Viana, B. F. \& I. Alves-dos-Santos. 2002. Bee diversity of the coastal sand dunes of Brazil. p. 135-153. In Kevan, P.G. \& ImperatrizFonseca, V. L. (eds.) Pollinating bees: the conservation link between agriculture and nature. Brasília, MMA.

Viana, B. F.; A. M. P. Kleinert \& F. O. Silva. 2002. Ecologia de Xylocopa (Neoxylocopa) cearensis (Hymenoptera, Anthophoridae) nas dunas litorâneas de Abaeté, Salvador, Bahia. Iheringia série Zoologia 92: 47-57.

Watmough, R. H. 1983. Mortality, sex ratio and fecundity in natural populations of large carpenter bees (Xylocopa spp.). Journal of Animal Ecology 52: 111-125.

Wittmann, D. \& E. Scholz. 1987. Nectar dehydratation and body weight reduction: the cues of Xylocopa nigrocincta to prolong duration of territorial flights. Chemistry and Biology of Social Insects. p. 724-725. International Congress of Social Insects, Munich.

Received 17/07/2007; accepted 11/08/2008 